\title{
The Innovation and Practice of Teaching Methods of Garment Design Courses --Guided by Fashion Trend Forecast
}

\author{
Yin Jun \\ School of Fashion, \\ Wuhan Textile University \\ Wuhan, China \\ E-mail: 12408113@qq.com
}

\begin{abstract}
The training mode of single technical talents has been insufficient to meet the development needs of current garment enterprise. Therefore,it is necessary to cultivate compound talents who are both highly sensitive to the international fashion trend and sharp to the feedbacks of domestic market and can independently accomplish series of system works including collection and management of information, judgment of the trend, product development and so on. From the perspective of system thinking, trend-forecast-oriented garment design courses make students have the ability of accurate awareness, overall thinking and in-depth analysis of fashion trends through the establishment of the teaching contents and teaching modules.
\end{abstract}

Keywords - Compound Talents; Fashion Trend; Orientation; Garment Design

\section{INTRODUCTION}

The cultivation of garment design talents closely relates to the demand of the development stage of the same industry. Chinese garment industry has began to participate in the international division of labor since the reform and opening up in 1978. In the 1980s and 1990s, the "designer" in the garment industry is a very vague career and clothing companies usually recruit pattern makers who not only know the models but also understand a little about design to replace designers, moreover, education institutions for cultivating garment designers are rarer. From 1990s to around 2000, garment industry starts the process of making brands. In 1993, the first Brother Cup International Fashion Design Competition introduces Chinese pioneering fashion designers with professional education backgrounds represented by "Wu Haiyan". At that time, branding is still at the stage of imitation and the development of brands takes the international brand as the goal and customer designers mainly refer to, imitate and modify the international brand products as well. After 2005, with the coming of information age, there are more and more cross interactions of clothing brands at home and abroad and the requirement of comprehensive strength of fashion designers is becoming increasingly higher. Influenced by the different levels of industrial development and regional difference, dozens of well-known professional colleges and universities of fashion design are established such as
Beijing Institute of Clothing Technology, Donghua University, China Academy of Art, Wuhan Textile University, etc. and on the cultivation of professional fashion talents, different cultivation modes are formed such as academic research and technical application.

After 30 years of development, as the external environment gets worse and internal competition intensifies, main competitive advantage of Chinese current clothing industry is no longer the cheap labor but a complete set of ecological structure. From the perspective of the development of the global textile industry, industrial upgrading is the trend of the times, the industrial chain will accelerate the integration and the enterprise will be facing the pressure of transition. The process of upgrading is the brand upgrading of high-end technology and transferring of low-end production to Southeast Asian countries. Therefore, the training mode of single technical talents has been insufficient to meet the development needs of current garment enterprise. It is necessary to cultivate compound talents who are both highly sensitive to the international fashion trend and sharp to the feedbacks of domestic market and can independently accomplish series of system works including collection and management of information, judgment of the trend, product development and so on. However, there are some problems about the training of compound talents in current teaching modes of universities.

\section{Present Situations And Problems of Teaching of GARMENT DESIGN}

The courses of Domestic fashion designs show two features. Firstly, comparing with that of inland cities, curriculum design of clothing major of garment industry developed cities such as the Pearl River delta and Yangtze River delta prefers professional education and cultivates applied talents. For example, Department of Textile and Costume Design in Shenzhen University combines market information with teaching and emphasizes on the combination of education and clothing industry. In the teaching process, it educates students with the case of special subjects and markets, entirely refers to mode of design and operation of clothing industry and cultivates applied talents. Textile and fashion Department of School of Art and Design in Shenzhen Polytechnic aims to 
cultivate talents with professional design ability, market analysis ability and communication and cooperation ability. Costume design courses adopt the subject-oriented teaching method through a series of assignment of corresponding subjects, such as brand clothing market research, analysis and collection of popular information, clothing brand planning, collection and management of materials and fabrics, serial garment design, etc. and take full-course appraisal method and record periodical score to promote the improvement of students' quality. In order to cultivate the creation ability of students, Quanzhou Normal University always emphasizes that in the process of teaching the students must be taught to know the theory of fashion design and master the methods of fashion designs and can make use of a variety of design elements to make a comprehensive performance at the same time strengthening the combination of design and market and society. Moreover, in the system of teaching contents, the university takes the principle of combining market and course. In the teaching process, teachers guide students to follow the market trend and combine the courses with garment enterprises and meet the requirements of contests of various topics. Secondly, in the development of clothing design, comprehensive colleges and universities will emphasize the teaching structures, teaching contents, teaching methods and curriculum modules according to the background of the preponderant disciplines. For example, Zhejiang Science and Technology University (former Zhejiang Silk Institute of Technology) has technical advantages and the disciplinary development of fashion design combines with the advantage of silk research and the research achievements of science and engineering which highlights key teaching points of clothing engineering and textile engineering. However, fashion design major of those colleges and universities on the basis of the art and design such as the Beijing Institute of Clothing Technology and China Academy of Art will give priority to art design or creative design in the perspective of curriculum design.

From the above curriculum designs and specialty directions of domestic garment design universities, it can be seen that costume design courses have detailed structure and pay attention to the cultivation of different abilities of students. However, there also exist intercommunity questions.

Cohesions between different subdivisions of curriculums are not quite close, each professional courses focus on independent courses and school homework lacks links which cause students lack a overview of systemic thinking of accomplishing clothing design work Most of the cultivation of applied talents takes the real market as the guidance and does not improve the ability of predicting the future market which can't promote Chinese clothing brand to lead the world fashion trend.

The transformation and upgrading of China's apparel industry raise further requirements to improve the students' comprehensive ability and the students' self development also requires the imperative teaching reform of clothing courses. Therefore, the design of costume courses must be around the design ability and prediction ability on the basis of industrial development to form systematic teaching modules.

\section{TREND-FORECAST-ORIENTED TEACHING MODELS OF GARMENT DESIGN COURSES}

From the perspective of system thinking, trend-forecast-oriented garment design courses make students have the ability of accurate awareness, overall thinking and in-depth analysis of fashion trends through the establishment of the teaching contents and teaching modules and combine the basic professional design method with the garment design method in order to master the development trend of garment market quickly.

\section{A. Course Teaching Objectives}

The course objective starts with the professional characteristics of garment design, then changes the teaching mode of traditional costume teaching content guided by real market and regards the development of future clothing fashion trend as the research object and transforms the students' learning goals and improves teaching results.

Starting with the discipline construction of fashion design, Wuhan Textile University makes use of its science background on the basis of garment design and opens up the industrial chain and subject chain through course design to form collaborative innovation of the disciplines including textile, material, clothing, machinery, cyclization, humanity, arts, management and media. 


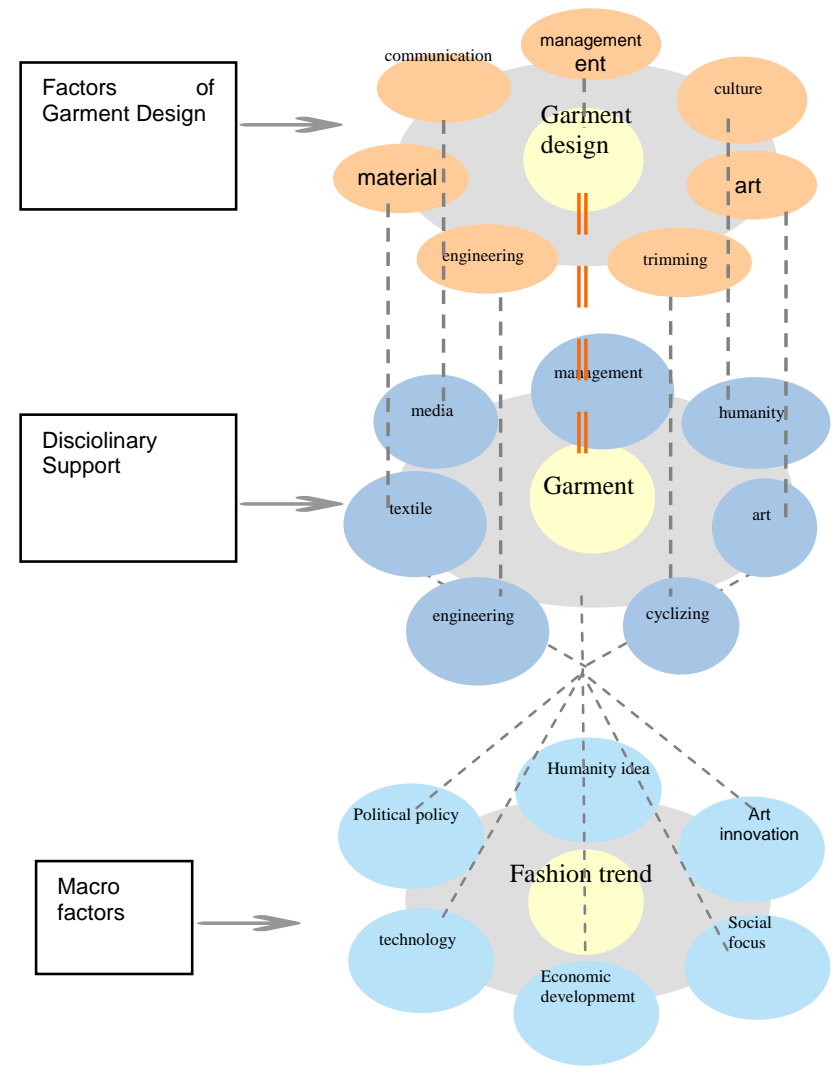

Figure 1 collaborative innovation of the interdisciplinary trend

\section{B. Content of Courses}

From the third year of fashion design major, garment design courses will be guided by the prediction of fashion trend.

The main contents of courses are as follows:

- Summarizing the basic definition of relevant trends and fashion trends, realizing the latest development of current popular trend and having a preliminary understanding of the design and fabrication of the trend concept;

- Fashion trend prediction is divided into five steps:information collection, information processing, resource integration, forecast analysis, design application and trend release. It is a gradual process from basic research to display and release. Researchers predict the possible trend in the future through exploring the basic materials of cultural, political, economic, environmental, social, science, technology and design with the combination of professional knowledge;

- Knowing the relationship between brand clothing design and Clothing fashion trend and theme clothing design; discovering how to apply fashion trend forecasting results into the theme design and design of brand clothing.

\section{Teaching Methods}

- "guide and explore"; using discovery method, exploration method, document investigation method to research four variable factors that affect the changes of garment market, namely the latest trend, haute couture brand release of big fashion weeks, representative clothing of fashion leaders and fashion media trend on the popular trend forecast website (WGSN, STYLESIGHT) and summing up the annual trend direction of real garment market through the principle of intersection;

- "project practice"; including practice method and experimental method; the final results of the course is trend forecast of women's clothing/ men's clothing/ children' clothing/ junior apparels/ sportswear/ casual wear/ leisure wear/ underwear of $201 *-201 *$ autumn/ winter (choose any one of the category). With three people a group and the real market (online or offline) survey as the foundation, accomplish the research forecast.

- "rational analysis"; Through rational analysis and statistics analysis of the macro environment variable factors including key events in politics, economic development trend, humanistic idea, art design, technology development level and social hot issues, it tries to find out the potential effects of the above factors that have on consumption concept, clothing consumption concept and the garment design concept of people;

- "Cooperation and Innovation"; Encourage students to think out of the box; establish a relationship with the professional practice of other textile universities; take trend prediction as the main body and design practice as results; integrate the scattered research results of other subjects; establish interdisciplinary cooperation and information sharing platform and a systematic and integrated approach to obtain more competitive scientific achievements.

\section{CONCLUSION}

Through 48 hours' garment design courses guided by popular trend prediction, the improvement of overall view of students' design and vision is obvious. Students have learned to use interdisciplinary toolbox and mastered the method to predict the fashion trend accurately and improved the design ability and meet the requirements of enterprises.

Since we are in the big data era, the fashion designers must hold open attitudes to learn about fashion and create fashion. Gary King, the sociology professor of Harvard once said, "The big data is a revolution and enormous data resource has made many fields start its quantitative process including the academic circles, the commercial circle and the government. All the fields will start this process in the future." Therefore, the 
development of China's clothing industry and disciplines are involved in this trend inevitably. The costume designers we want to cultivate can not stick to the old design methods to study the most fashionable field. Instead, they should pay close attention to the newest change of macro factors and costume designing. The basic design talents can not meet the development demands of clothing industry any more and only those creative designers with strategic ideas can create a "China style" in the fashion circle.

\section{REFERENCE}

[1].Xu Yichun, Reform and Exploration of Garment Design Course Construction-Discussion of the Reform Ideas and Measures of Our Garment Design Courses, Xianning College Journal, 2010, 30(11):142 143.

[2]. Li Rong, The Thinking of Garment Design Education under the Background of Globalization, Journal of Wuhan Textile University, 2011,24(2):23 26.

[3]. Ren Lihong, Methods and Approaches of Integrating Garment Design Courses with Market Demands, Journal of Jilin Engineering Normal University, 2014,30(1):73 75.

[4]. Xing Ying, Exploration and Practice of Project-oriented Teaching Method in the Garment Design Courses, Liaoning Silk, 2011,1:29 32.

[5]. Xiao Jingrong, Research on Teaching Mode of Garment Design under the Workshop Model, Shandong Textile Economy, 2012,7:97 99. 